\title{
La interpretación origeniana de Jn 1, 1-2: identidad del Logos en clave de relación
}

\author{
Fernando Soler \\ FACULTAD DE TEOLOGÍA \\ PONTIFICIA UNIVERSIDAD CATÓLICA DE CHILE \\ fasoler@uc.cl
}

Resumen: Este artículo presenta una lectura de los elementos que caracterizan la doctrina acerca de la identidad del Padre y del Hijo, presente en la interpretación de Orígenes a Jn 1, 1-2 contenida en los libros I y II de su Comentario a Juan. La clave de acceso es la categoría de relación, la cual está de trasfondo a toda imagen utilizada por el Alejandrino para describir al Padre o al Hijo, y brinda a su teología un dinamismo impresionante, a la vez que esboza soluciones a diversos problemas - como el de la generación del Logos- que marcarán de manera indeleble la doctrina trinitaria de los siglos posteriores. Con este fin, este trabajo se articula en dos partes complementarias. En la primera se muestra la identidad del Padre desde su relación con el Logos y, en la segunda, la identidad del Logos desde su relación con el Padre.

Palabras clave: Orígenes, Logos, Comentario a Juan, relacionalidad, Trinidad, subordinacionismo.

Abstract: This paper presents a study on the elements that characterize the doctrine of the identity of the Father and the Son, present in Origens interpretation of John 1, 1-2, in books I and II of his Commentary on John. The reading key is the category of relationship, which is the background of all images used by the Alexandrian to describe the Father and the Son, and gives to his theology an impressive dynamism, while sketch out solutions to several problems, such as the generation of the Logos, which indelibly marked the Trinitarian doctrine for later centuries. To this end, this paper is divided in two complementary parts. In the first, the identity of the Father is shown from its relationship to the Logos and, in the second one, the identity of the Logos from its relationship to the Father.

Keywords: Origen, Logos, Commentary on John, relationality, Trinity, subordinationism. 
En el presente artículo ${ }^{1}$ queremos mostrar que la identidad misma del Hijo de Dios, en tanto que Logos, solo puede entenderse si se ponderan adecuadamente las relaciones entre uno y otro, pues su identidad profunda es eminentemente relacional, lo que se basa en dos observaciones: por un lado, a) el mismo concepto logos no puede entenderse ni traducirse de ninguna manera que no evidencie una relacionalidad intrínseca y, por otro, b) es sabido que tanto en la filosofía antigua, como en la teología bíblica, el Logos es comprendido como un mediador -con mayor o menor grado de consistencia personal- entre Dios y el hombre. Ambas observaciones pueden ser recurrentemente constatadas al leer la Escritura, sobre todo, aunque no exclusivamente, la de ambiente griego, y también al considerar la teología patrística. Con el fin de sostener esta hipótesis, entonces, a continuación elaboraremos los elementos clave que expresan la identidad del Padre y del Hijo en clave relacional leídos específicamente en los libros I y II del Comentario a Juan (CIo).

\section{LA DIVINIDAD DEL PADRE COMO FUENTE Y DIVINIDAD SUBORDINADA DEL HIJO}

En el comienzo del libro $\mathrm{II}^{2}$ hallamos una constatación lingüística acerca del uso del artículo definido al hablar de Dios que nuestro autor considera clave en el lenguaje teológico del evangelista y, por tanto, lo asume como normativo.

El Alejandrino tiene la convicción que Juan realiza un uso preciso e intencionado del artículo determinado (ò) cuando este acompaña a $\theta \varepsilon o ́ s$, pues sistemáticamente lo utiliza $(\tau \alpha \dot{\sigma} \sigma \sigma \omega)$ o lo omite $(\sigma \omega \pi \alpha ́ \omega)$, dependiendo de si está nombrando al Padre o al Logos. En el caso del Padre, siempre utiliza el artículo (o $\theta \varepsilon o ́ s)$, pues así el Evangelista muestra que se está hablando del Padre, que Orígenes llama en II, 14 Inengendrado

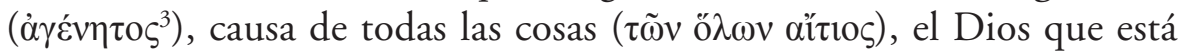

Este artículo ha sido posible gracias al PFCHA de CONICYT 21150485.

2 Orígenes, Comentario a Juan II, 12-18. De ahora en adelante, citaremos esta obra refiriendo solamente a su numeración interna. El texto griego, tomado de la edición de C. Blanc en Sources Chrétiennes 120 bis (Paris 1996), será referido, además, con su número de página.

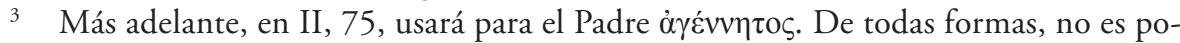
sible leer una intención teológica en el uso de ambos verbos, los que, al tiempo de Orígenes, parecieran ser intercambiables (Cf. P. Nemeshegyi, La Paternité de Dieu chez Origène [Tournai 1960], 62). De todas formas, la falta de precisión en el uso de estos términos, no comporta la misma ambigüedad cuando Orígenes explica la diferencia entre la forma de proceder desde del Padre del Logos y del mundo; como 


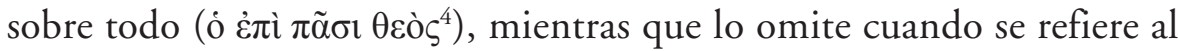

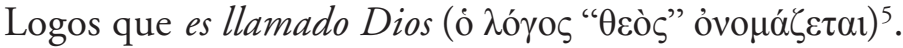

Esta distinción estaba ya presente en la teología alejandrina desde Filón ${ }^{6}$, sin embargo, dada la tratación eminentemente bíblica que hace nuestro autor, el influjo principal en este sentido lo constituye el prólogo mismo del Cuarto Evangelio, como lo afirman importantes autores ${ }^{7}$, y se puede corroborar a partir de una lectura atenta del CIo. En otros pasajes de esta obra encontraremos que Orígenes recurre a esta distinción también al referirse al concepto de Logos, para diferenciar el logos que tiene cada ser dotado de razón ${ }^{8}$ del Logos de Dios, y en VI, 45-46, para diferenciar el ser profeta de Jesús del profetismo de Israel.

De esta forma Orígenes, atendiendo la literalidad del uso lingüístico señalado, explicita una de las bases para la reflexión acerca de la particularidad de la divinidad del Padre, ciertamente fundada en su interpretación de la Escritura, aunque -como es habitual en la literatura cristiana antigua- entendida y explicada a partir de categorías presentes ya como patrimonio de la filosofía de su tiempo.

Ahora bien, la diferenciación entre lo específico de la divinidad del Padre y del Logos brota precisamente de una consideración de la divinidad del primero en cuanto principio. El uso del artículo definido revela precisamente esto, y Orígenes lo sostiene desde una lectura atenta del Evangelio según Juan, donde encontramos, además, otra pista clave en la oración de Jesús en la economía, donde llama vida eterna al conocimiento del único que es Dios Verdadero (Jn 17, 3), como recuerda Orígenes en II, 17. El Alejandrino, consecuentemente con su esquema de pensamiento,

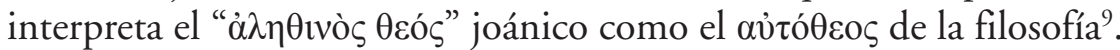

La denominación $\alpha$ v่tó $\theta \varepsilon \varepsilon^{10}{ }^{10}$ pareciera no tener en Orígenes otra finalidad que expresar la existencia fontal del Padre y la comunicabilidad

mostraremos, el Alejandrino es muy preciso al marcar una diferencia radical entre el orden eterno, donde coloca al Hijo, y el orden creado.

II, 15 .

Cf. II, 14.

Cf., por ejemplo, De Somn. I, 229.

Por ejemplo, Crouzel, comentando este pasaje, cita a K. Rahner, Écrits Theologiques I (Paris 1959) 94, apud H. Crouzel, Origène (Paris 1985) 238.

8 Cf. II, 14-15.

9 Cf. II, 17.

10 Corsini, siguiendo a G. Gruber, ZQH. Wesen, Stufen und Mitteilung des wahren Lebens bei Origenes (München 1962) 104 ss., comenta que "la composizione di nomi 
de su condición divina; es, además, el principio de comprensión para el uso diferenciado del artículo definido para referirse a Dios: solamente el

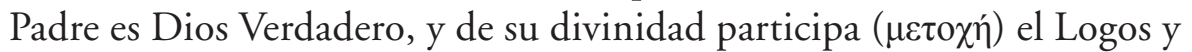
todos quienes participen -a través de él- de la divinidad; esta participación en la divinidad, diferentemente a la afirmación de los gnósticos, no se realiza por necesidad ${ }^{11}$, por una condición de la naturaleza, sino por una bondad libre de envidia (ä $\varphi$ oovos) del Padre ${ }^{12}$.

Más adelante nos haremos cargo de mostrar que la participación en la divinidad que posee el Logos es caracterizada por nuestro autor en categorías especiales, que lo diferencian del orden creado $^{13}$. Por otro lado, no ofreceremos una reflexión acerca de una subordinación en el sentido que se volvió relativamente clásico cerca de un siglo después de la muerte de Orígenes, pues escapa al propósito de nuestro artículo. En todo caso, un primer indicio en contra de una interpretación en este sentido la hallamos en un pasaje del libro II, donde afirma no solamente que el "primogénito de

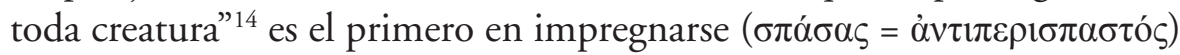

con il pronome av̉ós indica in primo luogo l'essere-in-sé, l'identità con sé stesso in contrapposizione con altri esseri, l'individualità. Non molto diffuso nel greco classico, quest'uso prende consistenza nel platonismo tardo e nel neoplatonismo, di cui diventa una delle caratteristiche". Gruber, a juicio de Corsini, junto con insistir en la originalidad del uso origeniano del compuesto, concluye que nuestro autor se inserta plenamente en el proceso del desarrollo del platonismo. Por otro lado, del hecho de

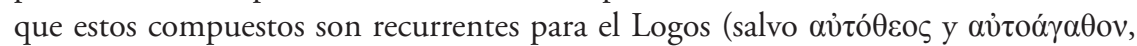
reservados para el Padre), concluye Gruber, y con él Corsini, que "si può vedere in questi attributi [los que incluyen el compuesto, aplicados al Hijo] la partecipazione primissima alla divinità che si attua nel Logos, nell'atto in cui la sua ipostasi si differenzia da quella del Padre". La importancia del uso del compuesto es clave pues, según estos estudiosos, "non si va forse lontano dal vero affermando che il Logos rappresenta nel sistema di Origene l'equivalente (personale e vivente!) del voๆtóv, cioè dell' ov̉oí $\alpha$, che nel neoplatonismo segue all'Uno" (E. Corsini, Commento al Vangelo di Giovanni di Origene [Torino ${ }^{2}$ 1995] 133, nota 17. De ahora en adelante citaremos esta traducción refiriendo, simplemente, al apellido del traductor). Estas afirmaciones, a nuestro entender, son precisas, y confirman nuestras intuiciones respecto al uso del compuesto en la sección investigada del CIo.

11 Respecto al tema de la necesidad en la generación del Logos y de su participación en la divinidad del Padre, cf. las luminosas palabras de H. Crouzel, Théologie de l'image de Dieu chez Origène (Paris 1956) 92, nota 89.

12 Cf. II, 17.

13 Como sucede, por ejemplo, en II, 17.

14 A nuestro juicio no se puede atribuir a Orígenes una lectura en categorías prearrianas del texto de Col 1, 15, pues esto no sería coherente con la diferencia radical que introduce entre el orden divino y el creado. Sergio Zañartu, haciendo 
de la divinidad y el más digno ( $\tau \mu \iota \omega ́ \tau \varepsilon \rho o \varsigma)$, sino que habla de su partici-

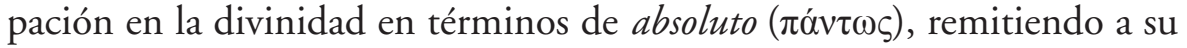

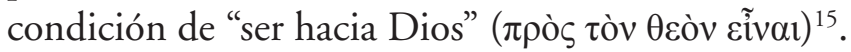

El problema que motiva a nuestro autor es particularmente difícil, ya que, además de la complejidad del hacer camino en campos aún no explorados suficientemente por la teología cristiana, va abriéndose paso, en temas trinitarios y cristológicos, entre modalistas y adopcionistas ${ }^{16}$, como se sigue del contexto en que se inserta II, 17, que comentaremos a continuación, donde lo encontramos ensayando respuestas al problema que resulta de afirmar, a la vez, la existencia real del $\mathrm{Hijo}^{17}$ y la monarquía divina, evitando -juntamente- reducir al Hijo a un mero modo de ser de Dios y afirmar la existencia de dos dioses. Veamos el planteamiento de la problemática que hace el mismo Orígenes:

"Y lo que agita a muchos que claman ser piadosos que, cuidándose de proclamar dos dioses, caen en opiniones erradas e impías, y resuelven [la dificultad] de esta manera: o [a] niegan que la individualidad del Hijo sea otra respecto a la del Padre, confesando a Dios ser llamado solamente de nombre Hijo; o [b] niegan la divinidad del Hijo,

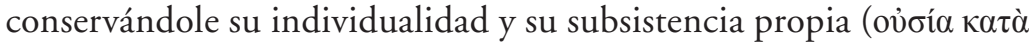
$\pi \varepsilon \rho\left(\gamma \rho \alpha \varphi \eta^{18}\right)$, siendo esta otra respecto a la del Padre"19.

un exhaustivo análisis del texto paulino en el CIo, le asigna a la teología del Logos de nuestro autor el concepto subordinacionismo moderado o jerárquico, probando que no es posible una aplicación tout court del apelativo subordinacionista a la teología del Alejandrino; cf. S. ZaÑARTu, "Primogénito de toda creatura $(\mathrm{Col} 1,15)$ en el Comentario de Orígenes al Evangelio de Juan”, en Teología y Vida 52 (2011) 105-151. Un estudio respecto a la posible aplicación al Hijo de categorías análogas al homoousios por parte de Orígenes es el de M. EDWARDS, "Did Origen Apply the Word Homoousios to the Son?”, en Journal of Theological Studies 49 (1998) 658-670.

15 Cf. II, 17.

16 Los señalamos con $a$ y $b$, respectivamente, en el texto que presentamos enseguida.

17 Cf. el pasaje II, 16, que enseguida traducimos. En él Orígenes utiliza términos

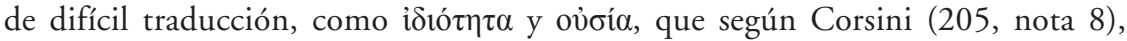
revelan cierta afinidad con el estoicismo. A juicio del estudioso italiano "ciò che dal testo sembra potersi dedurre con una certa sicurezza è sopratutto il concetto

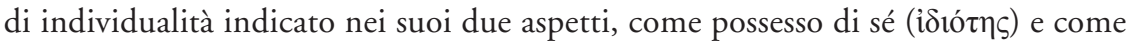

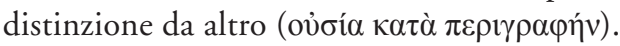

18 Un concepto muy cercano al estoico; cf. H. vON ARnim, Stoicorum Veterum Frag-

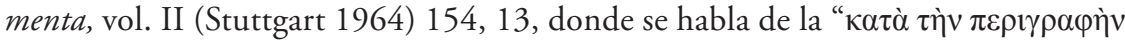

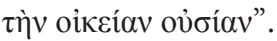

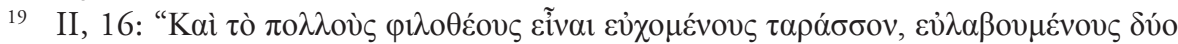

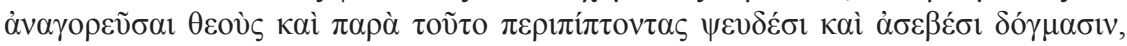


Por esta razón, la participación del Hijo en la divinidad del Padre, cuya mala formulación podría llevar a confesarlo como una creatura, será explicitada como teniendo una cualidad tan especial que no es analogable con ningún otro dios, de modo que todos los que no son el Logos son llamados genéricamente como los que "después de él son dios" (

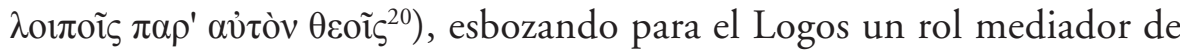
la divinidad que se aclara en II, 19, con la afirmación de que el Dios-

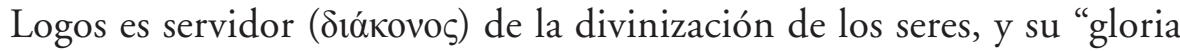

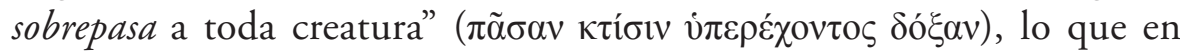

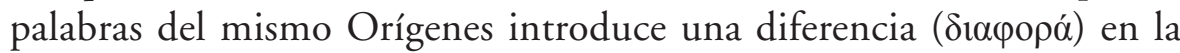
consideración del Logos y las creaturas ${ }^{21}$. Vemos, entonces, que a pesar de haber una subordinación del Hijo al Padre, se introduce una diferenciación radical entre el Logos y las creaturas ${ }^{22}$.

La relación subordinada entre el Padre y el Logos que hemos mencionado se extiende cuando nuestro autor considera el problema Trinitario: Orígenes obedece a la persuasión, una que le viene de la piedad, de que

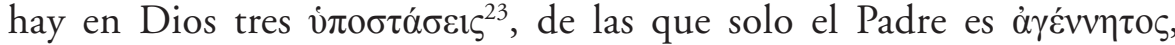
quien produce todo por medio de su Logos, incluido el Espíritu Santo ${ }^{24}$.

De esta manera se revela la fontal divinidad del Padre y cómo a ella corresponde una divinidad subordinada, aunque no accidental, del Hijo. Ahora bien, como hemos dicho, esta particular divinidad está li-

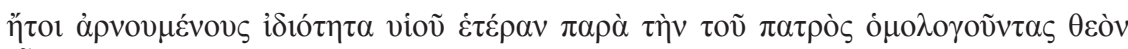

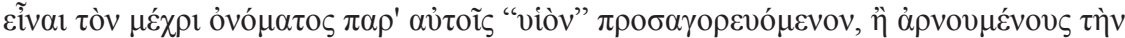

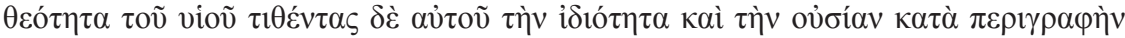

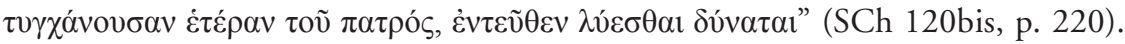
Otro texto en esta misma línea es el del Diálogo con Heráclides 4.

II, 17.

21 Un texto muy interesante en este sentido, es XIII, 151.

22 Cf. II, 17-19. En otros textos desarrollará más esta distinción radical entre Dios y las creaturas, sobre todo refiriéndose al carácter inmaculado, el que puede ser poseído o no, por las creaturas, mientras le pertenece substantialiter al Padre, al Hijo y al Espíritu Santo (cf. De principiis I, 5, 5).

23 Es importante no apresurarse al interpretar este término, el que ciertamente no tiene el sentido que se volverá técnico en los siglos siguientes (interesante en este sentido sería revisar Sch. In Matth. XVII, 309). En los textos trabajados nos parece

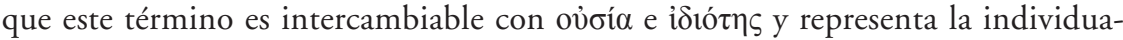
lidad del Padre, del Hijo y del Espíritu Santo, en cuanto distintos entre sí en un contexto en clara polémica con las concepciones modalistas.

24 Cf. II, 75-78. Respecto al tema del Espíritu Santo, puede consultarse la nota 20 de la edición de Corsini (p. 222). 
gada a una visión del Padre eminentemente como principio, lo que, finalmente, afirma su hegemonía. El siguiente apartado, en consecuencia, buscará mostrar y caracterizar el ser principio del Padre, lo que se refleja en que el Logos es su mediador, tanto en sentido creador como salvífico.

A. El Padre, principio absoluto, también de la actividad del Hijo

Hemos señalado hasta ahora que el Padre es Dios de un modo fontal e incondicionado, y que desde esta divinidad el Hijo recibe la suya. En el presente apartado trabajamos desde la hipótesis que, al investigar la relación entre el Padre y el Logos, puede apreciarse claramente en el CIo que el Padre posee, como característica primordial el ser principio, como lo afirma explícitamente Orígenes: "el Dios del universo es claramente principio, pues el Padre es principio del Hijo [...] y principio de los entes de manera absoluta" 25 .

Ahora bien, la reflexión de Orígenes acerca del versículo Jn 1, 1 se abre con una minuciosa consideración acerca de los múltiples significa-

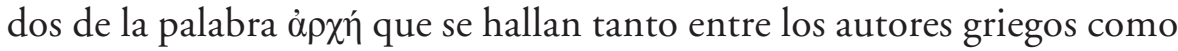
en la Escritura al referirse al Logos de Dios ${ }^{26}$. En la sección I, 90-111 nuestro autor examina seis sentidos, entre los cuales nos interesa espe-

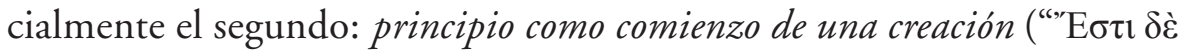

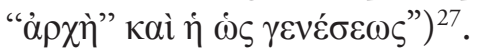

Luego de preguntarse, en el contexto del principio de la creación material, por los primeros seres creados en cuerpo (I, 96-98), lo que puede ser consecuencia de un castigo -como es el caso del gran monstruo mari$n o^{28}$-, pero que también puede ser escogido como un servicio, como el caso de Pablo" ${ }^{29}$, el Alejandrino afirmará que: "No [estará] fuera de lugar decir que el Dios del universo es claramente principio, porque principio del Hijo [es] el Padre, y principio de las cosas creadas es el creador, y, en general, principio de todos los seres [es] Dios"30.

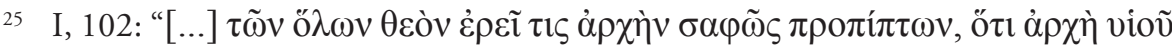

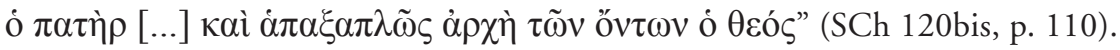

26 Cf. I, 90.

27 I, 95.

28 Cf. I, 96.

29 Cf. I, 100.

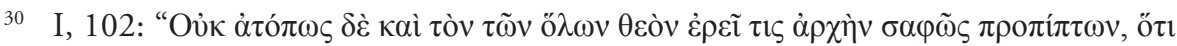

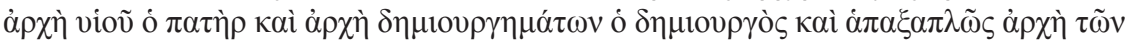

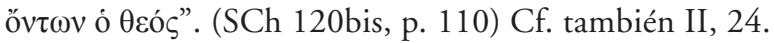


Esta convicción acerca del Padre, en cuanto principio en sentido general ( $\dot{\alpha} \pi \alpha \xi \alpha \pi \lambda \tilde{\omega} \varsigma)$, es la clave de lectura del versículo Jn 1, 1: el Logos es el Hijo, y está (Ẽ̃val) en el principio, es decir, en el Padre ${ }^{31}$ o, en

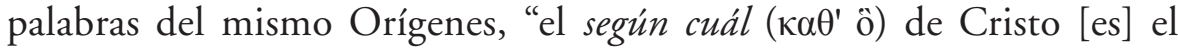
Padre-Principio" 32 , entendiendo la expresión " $\kappa \alpha \theta$ ' ô" como la referencia al arquetipo, a la causa en sentido ejemplar. De esta forma, vemos que el ser principio le corresponde propiamente al Padre, y el "primogénito de toda creatura", siendo imagen de Dios invisible y teniéndolo por principio, es llamado también principio, aunque en sentido secundario y con fin mediador-instrumental, pues él es "principio de los que llegaron a ser

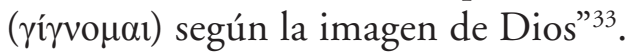

El ser imagen del principio del Hijo le viene de la voluntad del Padre, quien -similarmente a un constructor que tiene como principio de su

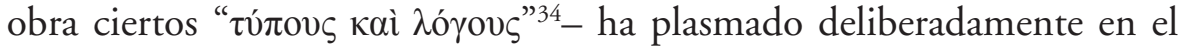
Hijo estas reglas ( $\lambda$ ó 01$)$, produciendo ( $\kappa \tau i \zeta(\omega)$ así una Sabiduría viviente

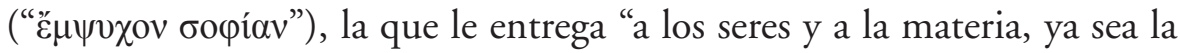
estructura, la forma [...] y la sustancia" 35 , todo esto, por encargo del Padre.

De este modo, también los cielos fueron consolidados mediante el Logos de $\operatorname{Dios}^{36}$ y creados los siglos ${ }^{37}$. Hemos dicho mediante, pues Orígenes es muy preciso en señalar que "todas las cosas llegaron a ser

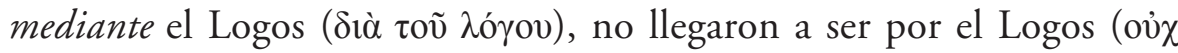

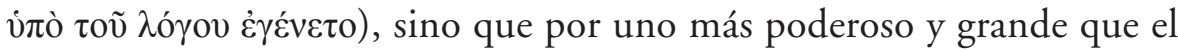
Logos ¿y quién otro puede llegar a ser, sino el Padre?" 38.

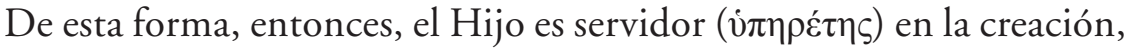
siendo el Padre demiurgo en sentido propio ${ }^{39}$.

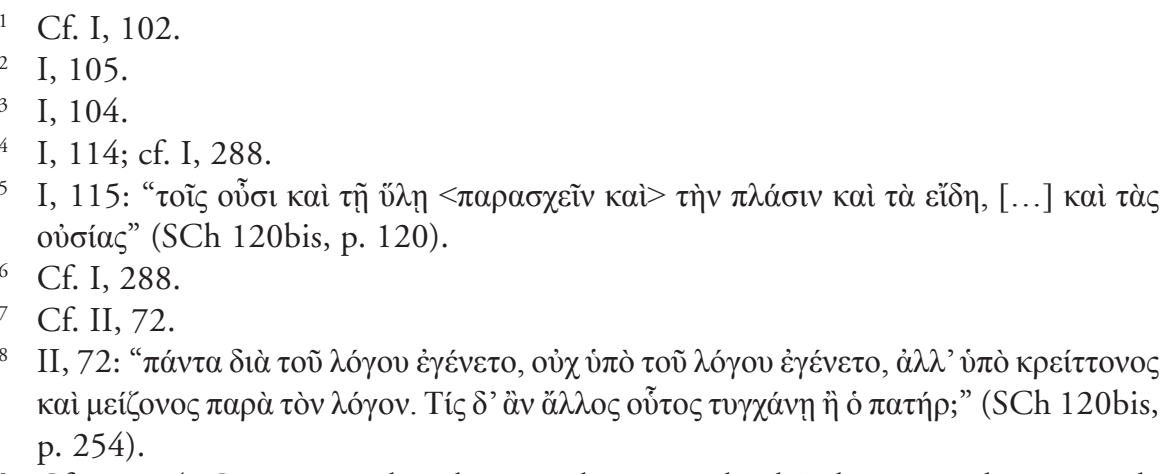

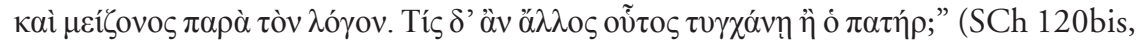
p. 254).

39 Cf. II, 104. Ciertamente la aplicación de este título al Padre tiene relación con la polémica contra quienes, junto a gnósticos y marcionitas, distinguen entre el Dios 
Ahora bien, respecto al tema del Padre en tanto principio absoluto, visto a partir de I, 102, es necesario subrayar que, en tanto que el Hijo es la Sabiduría, en él están -por voluntad del Padre- los logoi de todas las cosas. Según estos principios viene a la existencia toda la creación: él es Sabiduría en la formación del pensamiento que ha precedido todas las cosas y en la cual están sus nociones; es Logos, por otra parte, en tanto que comunica este pensamiento a los seres espirituales ${ }^{40}$. En este sentido, entonces, para Orígenes las nociones de Logos y Sabiduría son perfectamente aplicables al Hijo, aunque sin descuidar que la noción de

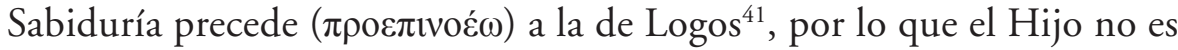
principio $^{42}$ en todas sus epinoiai, sino solamente en cuanto Sabiduría ${ }^{43}$.

En este sentido, también al analizar el tema de las epinoiai encontramos expresado el carácter prioritario del ser principio del Padre: él, siendo

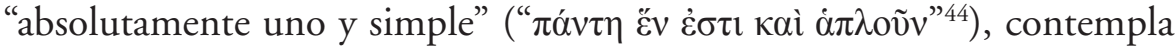
la multiplicidad de los seres y su necesidad de salvación. A esta multiplicidad, el Padre responde encomendando al Hijo una tarea mediadora, por

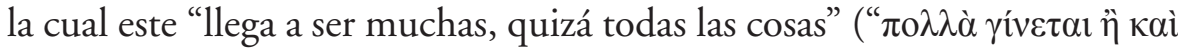

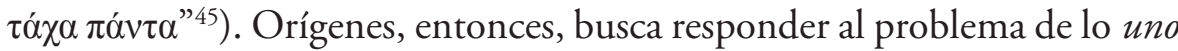
y lo múltiple en coherencia con su doctrina de la procesión del Logos, en el

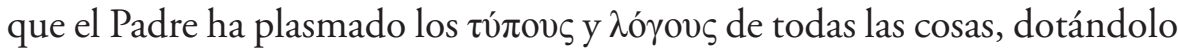
así de una capacidad para representar la multiplicidad.

Es muy importante, en este mismo contexto, considerar el comentario de Orígenes al Salmo 44, particularmente a las palabras "mi co-

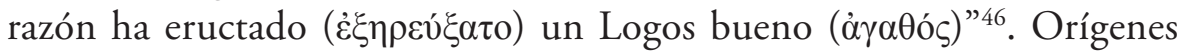

justo del Antiguo Testamento, demiurgo psíquico inferior, y el Padre del Cristo (Cf. E. Corsini, "Commento al Vangelo di Giovanni [Libri I-II]: Postille a Una Traduzione”, en Augustinianum 35 [1995] 193). Una rápida revisión al vocablo en G.W.H. Lampe (A Patristic Greek Lexicon [Oxford 1961] revela la variada asociación del término demiurgo entre los autores eclesiásticos aplicada al Padre, o al Hijo, o al Espíritu Santo.

Cf. I, 111

Cf. II, 90.

42 Este ser principio del Hijo, en cuanto Sabiduría, no debe entenderse como prioritario respecto al ser principio del Padre. Como hemos sostenido, solamente el Padre es principio en sentido propio.

43 Cf. I, 118

44 I, 119.

45 I, 119.

46 Cf. los parágrafos I, 280-288. 
interpreta el corazón del Padre como "su pensamiento y su poder de predisponer el universo" ${ }^{47}$, de este corazón, él exhala al Hijo, quien es el mensajero que anuncia la voluntad del Padre; en el Hijo-Logos el Padre

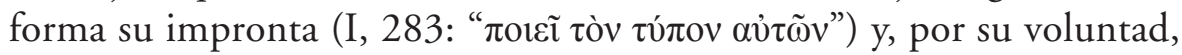
es que este llega a ser Verdad del Padre, comunicándose así a todos, según el mérito de cada uno ${ }^{48}$.

\section{B. La hegemonía del Padre}

Hemos visto hasta ahora la particularidad de la divinidad del Padre y el carácter de principio que posee. Pareciera que todo esto apunta claramente a afirmar el carácter hegemónico del Padre, como veremos a continuación.

En primer lugar, una afirmación general: el Padre es más grande que el $\mathrm{Hijo}^{49}$; y no solo en la economía de lo creado $^{50}$, sino que en sentido general, considerando todas las epinoiai del Hijo, incluso las más excelsas: “... Dios, el Padre de la verdad, es superior y mayor que la verdad, y siendo el Padre de la sabiduría más poderoso y excelente que la sabiduría, él excede a la «luz verdadera»"

Siendo sabiduría la epínoia más propia y antigua del $\mathrm{Hijo}^{52}$, y el Padre mayor a esta, podemos afirmar, consecuentemente, que el Padre es mayor que el Hijo también en aquello más propio del Hijo, que es ser Sabiduría.

\section{I, 282.}

48 Cf. I, 186.

49 Esta afirmación, proveniente de Jn 14, 28 deberá armonizarse, en el ejercicio exegético de Orígenes, con otros dos datos bíblicos que ciertamente conocía bien: a) la igualdad entre el Hijo y el Padre (cf. Fil 2, 6) y b) la unidad entre uno y otro (cf. Jn $10,30)$. La respuesta de nuestro autor a esta delicada problemática será su teología de la procesión del Logos y de la imagen, sobre lo que volveremos más adelante.

50 Cf. I, 255. Otro texto en que se afirma la excelencia del Padre en la economía, aunque con referencia a otra de las epinoiai principales del Hijo, es XIII, 19: "Y, quizá, saltará [el agua viva dada por Jesús] más allá de la vida eterna, hacia el Padre que está más allá de la vida eterna ( más grande que Cristo, más grande que la vida”.

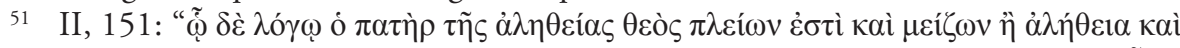

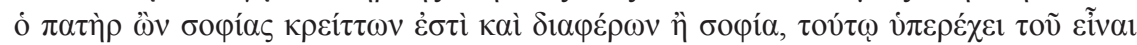

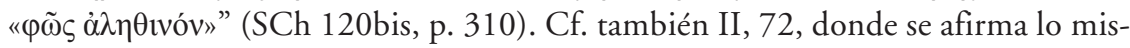
mo de la epínoia Logos.

52 Cf. I, 118. 
Esto se comprueba al leer las reflexiones de Orígenes al texto Jn 14, 28, sobre todo XIII, 151, donde, confrontando a Heracleón, coloca en relación el ser más grande con el apelativo bueno, reservado "en sentido soberano, verdadero y pleno" al Padre. De esta forma, entonces, el ser bueno es un apelativo que le conviene exclusivamente al Padre, denotando su hegemonía ${ }^{53}$ y su ser más profundo pues, como veremos luego a propósito del mal, nuestro autor asociará el término bueno al ser, por lo que la afirmación de Éxodo 3, 14 tiene su modelo hermenéutico en esta ratio ${ }^{54}$.

Así, entonces, debemos entender también los textos que afirman que el Padre es santificación, cabeza y justicia para el Hijo ${ }^{55}$. En ellos encontramos afirmada la hegemonía del Padre. Así, el Padre bueno se comu-

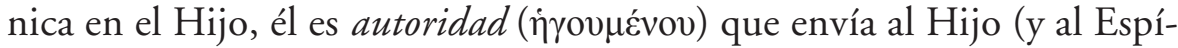
ritu) y promete venir en él para trabajar por la salvación del hombre ${ }^{56}$. En textos como estos vemos cómo Orígenes presenta al Padre como un Dios trascendente, pero no ocioso ${ }^{57}$; fuente él mismo de la acción inmanente y económica del Hijo y del Espíritu, pues en ellos actúa él mismo.

II. COMPRENDER AL LOGOS DESDE LA PERSPECTIVA DE SU RELACIÓN CON EL PADRE

A continuación centraremos la atención en elementos que, específicamente en la relación entre el Padre y el Logos, le corresponden primordialmente al Logos. Ya hemos mostrado al Padre como fuente de la divinidad, hegemónico y principio del Hijo, y ahora nos corresponde preguntarnos quién es este Logos que tiene su principio en el Padre, qué recibe de él, cómo le conoce y, finalmente, qué rol cumple en la comunicación ad extra del Padre.

A. El Logos recibe todo del Padre

Si bien pareciera un dato evidente, es necesario afirmar que en Orígenes hay perfecta identidad entre el Logos y el Hijo de Dios, él es "el mis-

53 Cf. I, 28 I, 254; II, 96; VI, 200; VI, 295: el Padre es bueno, el Hijo es imagen de su bondad, en este sentido también XIII, 234; XIII, 151.

54 Cf. II, 95-96. Muy interesante es colocar este texto junto al fragmento 2 del Comentario a los Efesios, de Orígenes.

55 Cf. I, 249; I, 252.

56 Cf. II, 83; I, 28.

57 Cf. H. Crouzel, Origène, 241. 
mísimo Hijo glorificado, el "Dios Logos»"58. De la misma forma como el apelativo Padre es usado comúnmente y sin necesidad de justificar su aplicación al Dios del universo, sucede con el apelativo Hijo ${ }^{59}$ aplicado al Logos. Esto también lo encontramos en el uso de otros nombres para el Logos, los que muy probablemente eran comunes en la piedad y teología de Orígenes y en el Nuevo Testamento, por lo que, salvo en pasajes en que se requiere un acceso técnico al concepto, son usados sin argumentaciones especiales, como por ejemplo Jesús, Señor, Cristo y Salvador.

Este Hijo, consecuentemente con la consideración del Padre en cuanto principio en sentido general -que mostramos anteriormente-, tiene como principio al Padre ${ }^{60}$, por lo que cuando se dice que el Logos está en el Principio, se busca afirmar que el Logos está en el Padre ${ }^{61}$ y, que en sentido absoluto, su genealogía última no reside en este mundo -es $\dot{\alpha} \gamma \varepsilon v \varepsilon \alpha \lambda o_{\gamma} \eta \tau \tau^{62} \varsigma^{6}$, sino que tiene su origen en el Padre.

En esta argumentación, Orígenes no solo busca, finalmente, afirmar la relación entre el Padre y el Logos y una especial realidad subsistente del Hijo, sino también la eternidad de esta relación, esbozando así su solución al problema monarquiano, y evitando que la hegemonía del Padre sea interpretada asignándole a) una existencia creatural al Hijo o b) una existencia no diferente del Padre.

Así, entonces, el Padre dice al Hijo las palabras del Salmo 2, 7: "tú eres mi Hijo, yo te he engendrado hoy". En la reflexión de estas palabras, Orígenes formulará contundentemente su teología de la generación eterna del Logos:

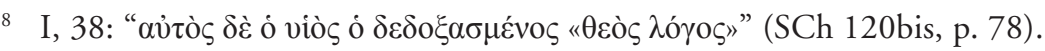

59 El Logos como Hijo en libros I y II (en negrita caso nominativo; con asterisco la

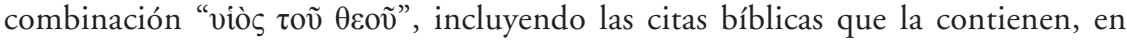
cualquier declinación): I, 11*; I, 28; I, 38; I, 40*; I, 52*-53*; I, 65*; I, 92-93; I, 102; I, 112*; I, 116*; I, 123-124*; I, 126*; I, 128*; I, 131*; I, 136*; I, 141*-142; I, 151*-152 (Logos=Hijo de Dios); I, 153*; I, 155*; I, 182; I, 187; I, 189; I, 191*; I, 193-194; I, 204; I, 205; I, 221*; I, 226*; I, 229*-230*; I, 236; I, 253; I, 263; I, 266*; I, 277-278; II, 4; II, 8*; II, 16; II, 20; II, 27*; II, 70*; II, 72; II, 74-76; II,

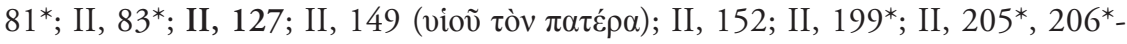
207*; II, 208; II, 217*; II, 219*, 220*-221*; II, 224*.

60 Cf. I, 104.

61 Cf. I, 102.

62 Cf. I, 21. 
"Pero a través de todo esto no se presenta claramente la noble generación del Hijo, y cuando el "Tú eres mi Hijo, yo te he engendrado hoy», dicho a él por Dios, para quien la eternidad es el 'hoy', pues no hay en Dios tarde ni mañana, sostengo, que más bien, el tiempo -si así puede decirse- coextensivo a su vida inengendrada y eterna (åî́o $\left.10 \varsigma^{63}\right)$, es para él este "hoy», en el cual es engendrado el Hijo, sin que lleguemos a descubrir ni el inicio ni el día de su generación" ${ }^{34}$.

De esta forma, entonces, se propone en la teología de Orígenes un esquema correlativo ${ }^{65}$ en la comprensión de las personas del Padre y del Hijo. No puede pensarse uno sin el otro, tampoco un tiempo en que uno u otro no estuviera; mucho menos, aunque redunde al decirlo, un tiempo en que el Hijo no estuviera siendo generado por el Padre, lo que coloca una neta distinción entre el Hijo y las creaturas. Esto se reafirma por el uso preciso de los vocablos: no es como en la economía en la

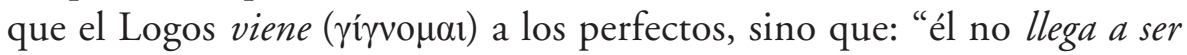

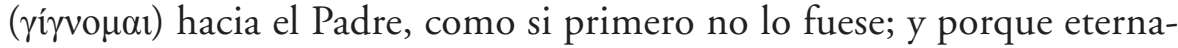

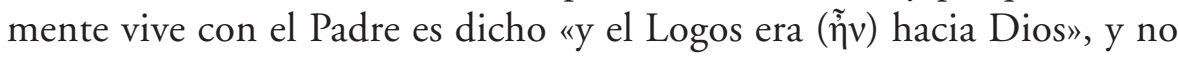

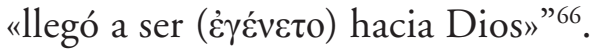

63 El término usado es muy preciso, y no comporta las ambigüedades que pudiera

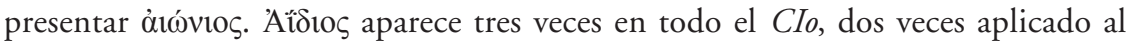
Padre (I, 204; XIII, 153) y una al Hijo (XIII, 48). Este concepto se volverá técnico para referirse a Dios, contrario al uso neoplatónico para referirse al universo como coexistente a Dios (cf. voz Aïolos en LAMPE).

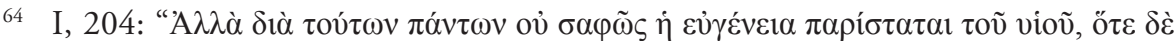

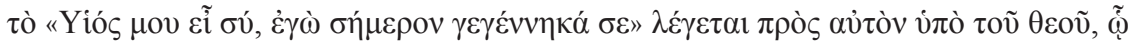

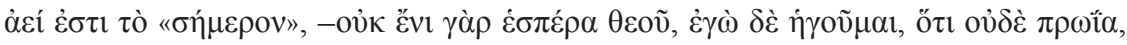

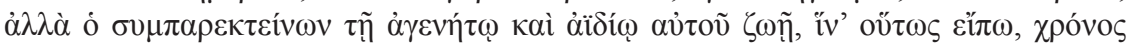

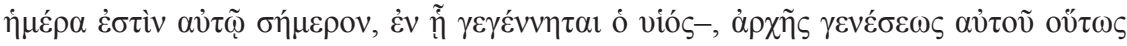

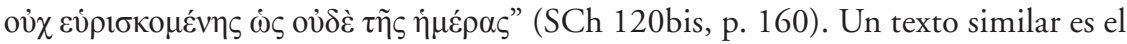
clásico In Ieremiam IX, 4.

65 El término que usamos es el evidenciado por X. Morales, La théologie trinitaire d'Athanase d'Alexandrie (Paris 2006) 201-231, quien sigue a M. Boulnois, Le paradoxe trinitaire chez Cyrille d'Alexandrie. Herméneutique, analyses philosophiques et argumentation théologique (Paris 1994). Este concepto depende de la categoría platónico-aristotélica, $\sigma \chi \varepsilon \dot{\sigma} \sigma l \varsigma$ (cf. Aristóteles, Categorías, 7, 6a), que revela la co-

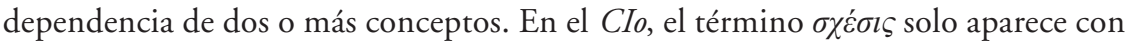
este sentido técnico en II, 205, referido a la relación "entre el Padre y el Hijo y del Hijo con el Padre".

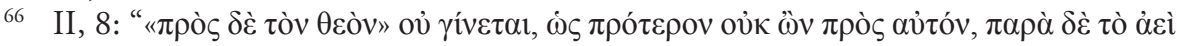

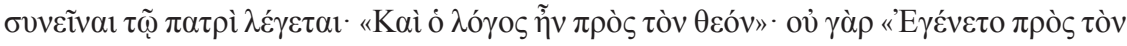

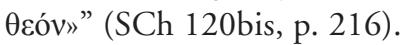


Por esta razón el Logos nunca estuvo ni "separado ( $\chi \omega \rho ı \zeta o ́ \mu \varepsilon v o \varsigma)$ del

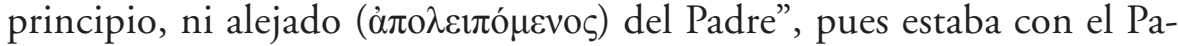
dre "antes de todo tiempo y eón" ${ }^{67}$. Esta es la forma en que Orígenes entiende el ser Hijo del Logos, y más adelante veremos cómo este modo de ser hacia el Padre le vale al Hijo recibir todo de él.

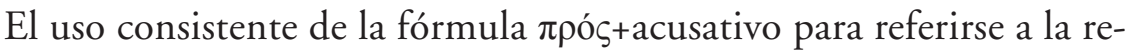
lación del Logos con el Padre -que ciertamente proveniente de la lectura de Jn 1, 1-2-, permite a Orígenes enmarcar esta relación en la categoría $\sigma \chi \varepsilon \dot{\sigma} \sigma \varsigma$, , lo que reafirma la necesidad de comprender los nombres Padre e Hijo como conceptos correlativos ${ }^{68}$. Orígenes utiliza este argumento para afirmar la coeternidad de ambos, y es la base de su formulación de la generación eterna del Logos, rechazando contundentemente la posición monarquiana al afirmar la existencia real del $\mathrm{Hijo}^{69}$.

Otra afirmación que muestra la identidad correlativa del Logos, es la de su ser según el Padre, lo que está en relación con la causalidad ejemplar presente en el Padre en cuanto principio del Hijo. En Orígenes esto se prueba por la aplicación al Logos de las expresiones -ciertamente pla-

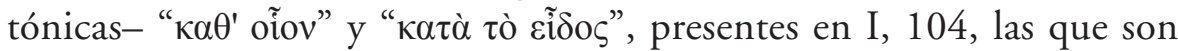

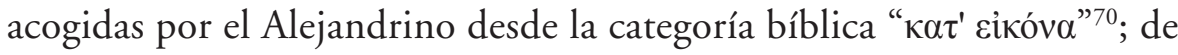
esta forma, entonces, "si el primogénito de toda la creación es la imagen de Dios invisible, el Padre es su principio"71: el ser principio de Padre de manera general ( $\dot{\alpha} \pi \alpha \xi \alpha \pi \lambda \tilde{\omega} \varsigma)$, en el Hijo comporta la peculiar carac-

67 II, 9.

68 "L'argument des corrélatifs» est simple: il consiste en ce que «il ne peut y avoir de père sans fils»" (Cf. M. Boulnois, Le paradoxe trinitaire, 387, apud X. Morales, La théologie trinitaire d'Athanase, 203).

69 Cf. además de los pasajes citados, X, 246 y De principiis I, 2, 2. Para una visión de conjunto del problema monarquiano, ver S. FERNÁNDEZ, "La generación del Logos como solución al problema monarquiano, según Orígenes”, en S. FERnÁNDEZ - J. Noemi - R. Polanco (eds.), Multifariam. Homenaje a los profesores A. Meis, A. Bentué y S. Silva. Anales de la Facultad de Teología (Santiago 2010) 193-229.

70 Cf. I, 105; II, 20.

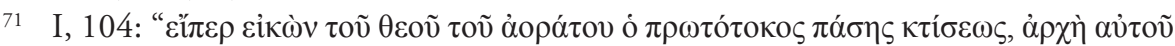

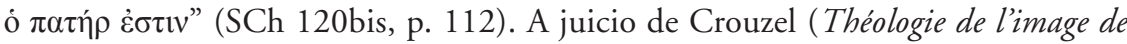
Dieu, 78), la categoría imagen "exprime une relation d'origine: le Père est la source de la divinité du Fils", lo que prueba a partir de este mismo texto. Poco más abajo, en la misma página, afirma "D’après la terminologie propre à Origène et prise au platonisme, si le Christ est l'image le Père est sa "véritê", c'est-à-dire son modèle. Ces termes ne font-ils que traduire la relation d'origine”, advirtiendo, a la luz del Fragm. in Io VI, que verdad no se opone a mentira, sino a imagen. 
terística de plasmar la propia imagen, lo que, a su vez, revierte en que el Logos sea, para todos los seres racionales, la imagen arquetípica, desde la que son plasmados ${ }^{72}$.

A nivel de la economía y del rol salvador del Hijo, en consecuencia con la teología mística de Orígenes ${ }^{73}$, en el Logos encarnado hallamos también esbozada una comprensión aparentemente dinámica del ser imagen del Padre, al afirmar, con el carácter zetético que caracteriza a nuestro autor, que "la bondad de Cristo se ha manifestado más plena, divina y verdaderamente a imagen del Padre" en su humildad y entrega por la salvación del hombre ${ }^{74}$, este rol de servidor lo ha recibido del Padre ${ }^{75}$.

Ahora bien, este mostrarse más conforme a la imagen, no debe ser comprendido separadamente de las afirmaciones acerca de la coeternidad del Hijo que hemos realizado más arriba ${ }^{76}$, por lo que no parecieran implicar un cambio en la esencia, sino en el acontecer económico del Logos encarnado. Esto previene cualquier lectura que pueda debilitar la unidad y la coeternidad de la relación entre el Logos y el Padre, como se sigue, además, del mencionado argumento de los correlativos respecto a la procesión del Logos. El ser imagen del Padre, es comprendido por el Alejandrino en sentido intelectual ${ }^{77}$, lo que en su pensamiento, en coherencia con el Evangelio de Juan, debe entenderse en un sentido exis-

Cf. II, 18; I, 283.

73 Sobre este tema, cf. lo que diremos a continuación acerca de las epinoiai.

74 Cf. I, 231.

75 I, 232.

76 Por lo demás, el ser imagen de Dios le corresponde principalmente al Logos-Dios, no al Logos encarnado (cf. H. Crouzel, Théologie de l'image de Dieu, 75).

77 Este sentido intelectual, creemos, tiene una componente vinculada con el tema de la unidad por la voluntad entre el Padre y el Hijo, el que, en el CIo se encuentra condensadamente formulado en XIII, 228. Acerca de la interpretación de este texto, ver $\mathrm{H}$. Crouzel, Théologie de l'image de Dieu, 91-92 donde nos parece que se hace una interesante diferenciación que previene de una comprensión, digamos, demasiado débil de la unidad, o puramente moral: la vinculación con la voluntad no tiene que ver con la generación, sino con la imagen: "Le Fils est image du Père, parce qu'il accomplit tout ce que veut son Père, parce que sa volonté est l'image de celle de son Père, ou même ne fait qu'une avec celle de son Père" (H. Crouzel, Théologie de l'image de Dieu, 92). Por otro lado, recordemos el texto del De principiis IV, 4, 1, donde se usa para Cristo el título filius charitatis, en paralelo a Hijo de la voluntad (cf. H. Crouzel, Théologie de l’image de Dieu, 95). Similarmente piensa C. BlanC ("Jésus est fils de Dieu: L'interprétation d'Origène”, en Bulletin de Littérature Ecclésiastique 84 [1983] 5-18, especialmente 16): la voluntad divina reside total y sustancialmente en el Hijo, 
tencial: el Logos es Sabiduría que Dios "establece como principio de sus caminos, en vista de sus obras" ${ }^{\prime \prime}$, razón por la cual, el Padre se regocija

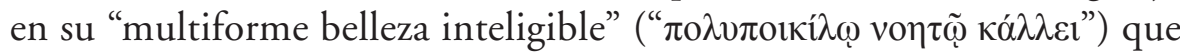
seduce a quienes la contemplan ${ }^{79}$.

Ahora bien, hemos mostrado que el Logos es Hijo y que tiene inicio en el Padre, del que es imagen, pero ¿qué sucede, a nivel de la existencia, con su sustancia? ¿Es distinta a la del Padre? Es evidente que no hallaremos en nuestro autor las precisiones terminológicas posteriores para responder estas preguntas, sin embargo, Orígenes se enfrenta al problema y esboza soluciones que debemos considerar cuidadosamente.

Anteriormente, a propósito del Padre, hemos revisado la interpretación de Orígenes del Salmo 44, $2^{80}$ ("mi corazón [el del Padre] ha

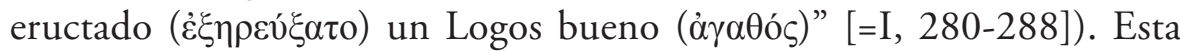
interpretación se realiza, precisamente, en un contexto polémico contra la multitud que, si bien cita bastante este texto, pareciera no comprenderlo adecuadamente ${ }^{81}$. Para nuestro autor, el corazón del Padre debe entenderse como su "poder de pensar y predisponer todas las cosas" mientras que el Logos sería quien anuncia aquello que está oculto ${ }^{83}$.

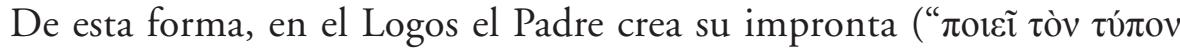

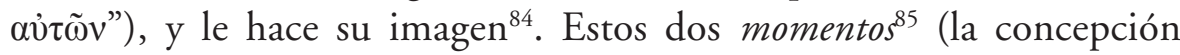
mental de la Sabiduría y su eructación) asegura, por un lado, la relación y, por otro, la existencia diferenciada de Padre e Hijo.

en los santos se halla presente parcialmente y por participación. La voluntad del Padre y del Hijo son una sola; cf. especialmente XIII, 228.

$78 \operatorname{Pr} 8,22$.

79 Cf. I, 55.

80 Este texto había sido usado en relación a la generación del Hijo ya antes de Orígenes por Justino, Teófilo y Tertuliano. Después de nuestro autor, será usado por Atanasio (cf. la nota 2 de la edición de Blanc, en página 205).

81 Cf. I, 280

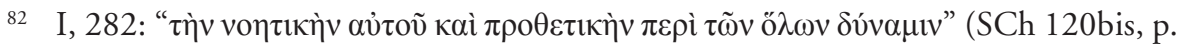
202).

83 Cf. I, 282.

84 Cf. I, 283.

85 En ningún caso debe entenderse en sentido temporal este concepto, es solamente una conceptualización. Respecto a la necesidad de aplicar comparaciones del ámbito temporal, con el fin de comprender algo de la relación entre Padre e Hijo, Orígenes se había referido, por ejemplo, en De principiis I, 2, 4). 
La interpretación de la multitud acerca de este salmo -que podríamos denominar modalista-, aunque quizá también de los valentinianos ${ }^{86}$, ya había impuesto al Alejandrino la necesidad de reflexionar algunos elementos clave en torno al tema de la sustancia del Hijo, sobre todo acerca de su existencia, digamos, realmente distinta a la del Padre, pues ellos "piensan que el Hijo de Dios es un modo de decir ( $\pi \rho \circ \varphi \circ \rho \alpha ́)$ del Padre que está en las sílabas y, según esto, si les preguntamos con precisión, no le

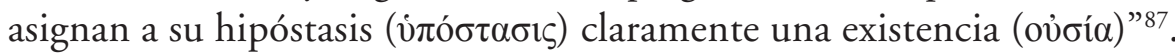
Nuestro autor, reconociendo la dificultad de concebir que una palabra sea un Hijo, comprende que no puede renunciarse a confesar al Logos

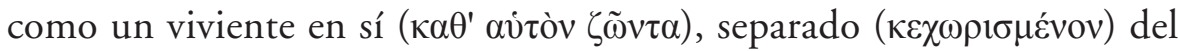

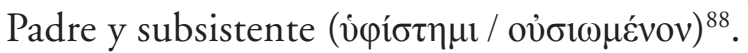

Orígenes, como vemos, debía defender la monarquía sin debilitar el dato trinitario y viceversa. Esto evidentemente no era fácil, tanto así que otros -además de la multitud-por una piedad sin mucha reflexión, "niegan al Hijo una individualidad distinta de la del Padre" alguna de las alternativas insuficientes más fáciles: negar la divinidad

86 Cf. Ireneo, Adv. Haer. II, 42, 3-4: "Vos autem generationem eius ex Patre divinantes, et verbi hominum per linguam factam prolationem transferentes in Verbum Dei”, citado por Blanc en su nota 2, página 134. Corsini no cree que deba incluirse a los valentinianos entre los destinatarios directos de la polémica de este pasaje, sino simplemente a la multitud (cf. su nota 45 en página 160 de su traducción). Nos parece más atractiva la opción de Blanc, es decir, pensar en un espectro más amplio de destinatarios para esta argumentación; lamentablemente, no es posible hacer para el texto de Ireneo un paralelo entre el latín y el griego de los fragmentos, pues no hallamos vocablos afines a đ@opo@ó en B. ReYNDERs, Vocabulaire de la "Démonstration" et des fragments de Saint Irénée (Chevetogne 1958).

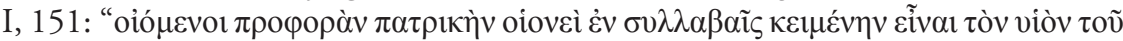

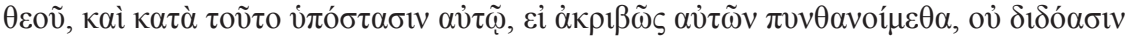

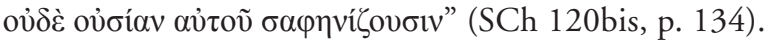

Cf. I, 152. Un texto muy interesante respecto del combate con los modalistas es el

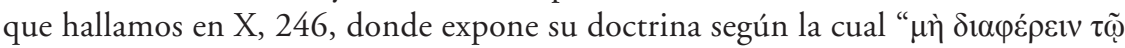

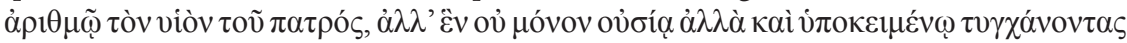

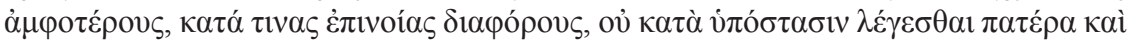
vióv" (SCh 157, p. 530). Este texto es clave por la utilización precisa de los conceptos, donde se coloca a la ov̉oía como el lugar correcto para referir la unidad, mien-

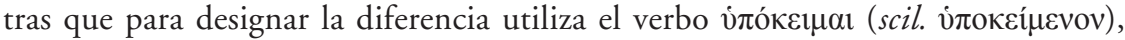
como aquello que distingue a la persona. Además, la distinción meramente mental,

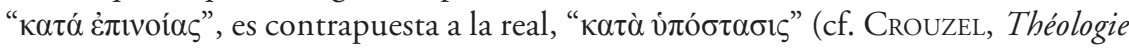
de l'image de Dieu, 103).

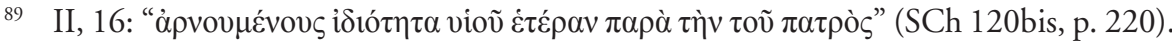


del Hijo -como lo hace el adopcionismo-, o negar su individualidad

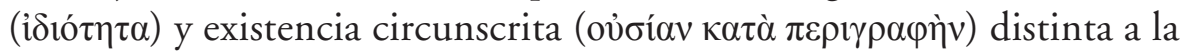
del Padre, como lo hace el modalismo ${ }^{90}$.

Otro dato tradicional que el Alejandrino debía custodiar respecto a la interpretación del Salmo 44, 2, es la absoluta incorporalidad de Dios, por lo que en el CIo evita explicar la procesión del Logos con analogías referidas a la generación humana, pues esto supondría una división en la sustancia paterna ${ }^{91}$. En este esfuerzo hallamos la interpretación que hace Orígenes del Salmo 44, 2, donde hemos visto que compara la generación del Logos con el acto de pronunciar una palabra, cuyo concepto preexiste en la mente y, en este sentido, se entiende: Logos y Sabiduría parecieran estar indisolublemente unidos ${ }^{92}$.

Así el Logos, que es también Sabiduría de Dios, si bien, como hemos mostrado recibe su existencia desde el pensamiento del Padre -de modo análogo al arquitecto-, no tiene su existencia en meras representaciones

90 Cf. II, 16. Respecto al aporte de las categorías estoicas para comprender este tema en Orígenes, es interesante el trabajo de J. Rius-CAMPS, quien afirma que "en la

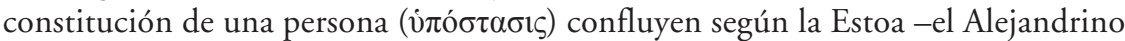
ha adoptado y asimilado sus categorías- la esencia (ov̉oía), como conjunto de pro-

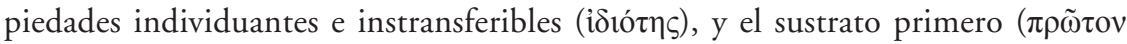

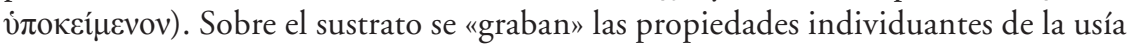

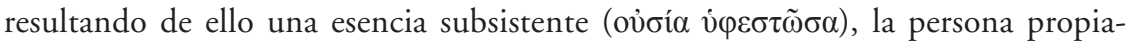
mente dicha, dotada de operaciones responsables y de independencia de acción” ( $E l$ dinamismo trinitario en la divinización de los seres racionales según Orígenes [Roma 1970] 81).

91 En este sentido, preferirá otras imágenes, como se puede apreciar, por ejemplo, en De principiis I, 2, 4.7 y IV, 4, 1.

92 En todo caso, si bien teniendo a la vista solo estos textos podría pensarse que Orígenes concibe la generación del Logos como un acto meramente externo del Padre, no podemos sino entender estos pasajes a la luz del uso coherente, en la obra del Alejandrino, de imágenes del talante de tamquam splendor e luce o tamquam voluntas a mente, como señala Crouzel en Théologie de l'image de Dieu, 85. Estas expresiones resaltan la unidad, a la vez que la diferencia. De todas formas, señala el estudioso francés, "le caractère de manifestation extérieure est inhérent à toutes les réflexions d'Origène sur la génération du Verbe: n'oublions pas en effet que pour lui le Logos est médiateur par sa divinité même, et non seulement par suite de son Incarnation. Nous avons là un des schèmes fondamentaux de sa christologie" (Théologie de l’image de Dieu, 85). Ver también J. Rius-CAmps, “¿Subordinacianismo en Orígenes?”, en L. LiEs (ed.), Origeniana quarta (Innsbruck 1987) 171-172, para quien la fórmula tamquam a mente voluntas sería la más propia para explicar la generación inmaterial del Hijo. 
mentales ( $\psi 1 \lambda \alpha i \tilde{\varsigma} \varphi \alpha v \tau \alpha \sigma i \alpha ı)$ ) de Dios, como puede ser el pensamiento del hombre ${ }^{93}$, sino que es una subsistencia incorporal ( $\left.\alpha \sigma \omega ́ \mu \alpha \tau o v ~ v i \pi o ́ \sigma \tau \alpha \sigma v\right)$,

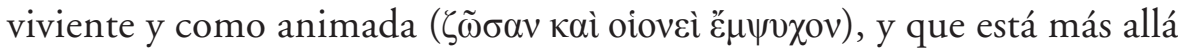
de toda creatura $(\dot{v} \pi \dot{\varepsilon} \rho \pi \tilde{\alpha} \sigma \alpha \nu \kappa \tau i ́ \sigma v)^{94}$. El Logos, entonces, recibe del

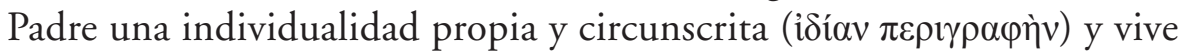

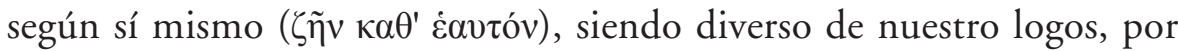
el cual participamos del Logos en sentido propio, y cuya existencia depende de su fuente, que es este Logos de Dios ${ }^{95}$. Esto lleva a una clara

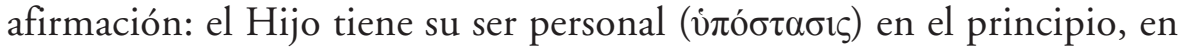
la Sabiduría ${ }^{96}$.

Recibir la existencia del Padre implica para el Logos, entonces, recibir todo del Padre, también su divinidad: el Padre es el único Dios verdadero, como hemos visto, y fuente de la divinidad ${ }^{97}$, él es la divinidad en sí, el prototipo, y el Logos su arquetipo ${ }^{98}$ respecto a los seres racionales. Orígenes define el ser del Hijo por su ser ( en esa intimidad es su característica ontológica más propia, lo que le

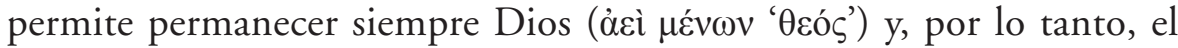
Logos recibe su divinidad de la perseverancia en la "contemplación ince-

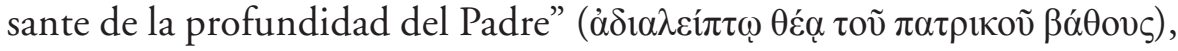
la cual, en el caso hipotético de cesar, le costaría al Logos la pérdida de su estatus divino ${ }^{99}$.

Con esta proposición hipotética pudiera parecer que nuestro autor introduce una accidentalidad, temporalidad o debilidad ontológica del

93 Cf. I, 243.

94 Cf. I, 244. Un texto mucho más explícito es De principiis I, 2, 2, muy relevante dada su similar data de composición.

95 Cf. II, 20.

96 Cf. I, 291-292. En este sentido, es importante recordar que la reflexión de Orígenes acerca de los pasajes de las Escrituras tiene como principio hermenéutico su unidad, por lo que su comprensión debe hacerse desde textos como Sab 7, 26

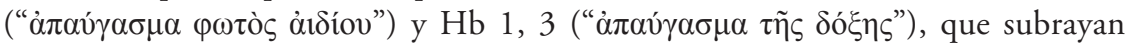
ciertamente, junto con las analogías respecto al concepto imagen, la eternidad de la relación y la permanencia o constancia de la generación (cf. Crouzel, Théologie de l'image de Dieu, 87-88).

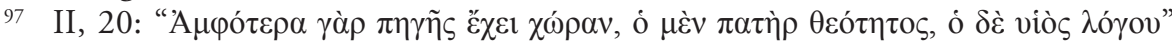
(SCh 120bis, p. 226).

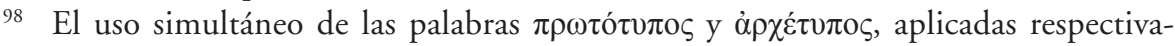
mente al Padre y al Hijo, se halla en II, 18.

99 Cf. II, 18, donde corresponden las precedentes citas. 
Hijo o de su divinidad ${ }^{100}$, sin embargo una interpretación de este género no es posible pues, como hemos visto, el Hijo es engendrado eternamente por el Padre: comprometer su filiación es comprometer la paternidad y eternidad del Padre; recordemos el pasaje ya citado I, 204, donde se afirma que el hoy en el que el Hijo es engendrado, corresponde al hoy de la eternidad de Dios ${ }^{101}$, en el que viven en un relación dinámica e íntima.

Esta relación implica, además, que el Hijo conoce al Padre de manera única, al modo formulado por Mateo: "Nadie conoce al Padre, si no el Hijo y a quien el Hijo se lo revele"102. El conocimiento que tiene el Logos del Padre, la perfección de su contemplación o comprensión (como

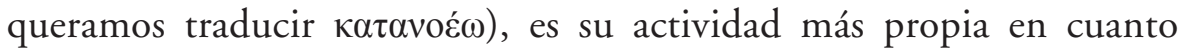
$\mathrm{Hijo}^{103}$. En esta actividad serán asociados los perfectos en la parusía ${ }^{104}$.

De esta forma, entonces, es clara la correlatividad del Padre y del Hijo, la que no debe comprenderse de manera estática (recordemos la generación eterna en el hoy del Padre), sino dinámica y gozosa (el Padre

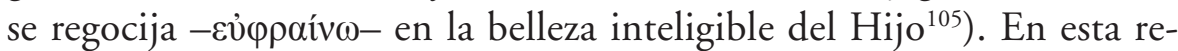
lación, de todas formas, es evidente una subordinación del Hijo ${ }^{106}$ que impone una relación de proporción, pues "el logos que está en todos los seres racionales tiene respecto del Logos que está en el principio hacia

100 La posibilidad del Hijo de ser, sin ser a la vez Dios, ciertamente es una suposición hipotética, y claramente en esta línea piensa Orígenes, pues para él, tal como lo explica Crouzel, "le Fils possède la divinité, comme d'ailleurs toutes les vertus, de façon substantielle, c'est-à-dire qu'il se confond avec elles, que sa divinité ne fait qu'un avec son existence: alors que les créatures logikai ne participent à la nature divine qu'accidentellement" (H. Crouzel, Théologie de l'image de Dieu, 86).

101 El fragmento 88 del CIo, conservado en la Apologia de Panfilio (Pr 563) señala: "Unigenitus enim natura Filius et semper et inseparabiliter Filius est". Muy iluminador, en este tema, es el pasaje que hallamos en el mismo CIo, en XX, 253-260.

102 Citado por Orígenes en I, 278. Cf. también I, 260, donde se afirma que el Hijo es el " $\mu$ óvo $\tau \varepsilon$ ó $\rho \tilde{\omega} v \tau$ òv $\pi \alpha \tau \varepsilon \dot{\varepsilon} \rho \alpha$ ".

103 Cf. I, 92-93.

104 Cf. I, 92-93 (sic.).

105 Cf. I, 255.

106 Una subordinación que, como se ve, no toca ni la esencia, ni la eternidad del Logos. Respecto a la aplicación del apelativo subordinacionista a la teología de Orígenes, ver nuestra nota 16 , también, respecto a este tema, puede consultarse el estudio de J. Rius-CAmps, “¿Subordinacianismo en Orígenes?”, 154-186, pero especialmente las páginas 159-161, donde analiza la aplicación de verdad a Cristo en el CIo. 
Dios, el Logos Dios, la misma razón ( $\lambda$ óyov, en el sentido de razón o proporción) que el Logos que es Dios tiene respecto a Dios [Padre]"107.

Este tema vuelve a aparecer en II, 166 en un contexto referido a la encarnación, y lo hallamos claramente en II, 151, donde encontramos un texto que afirma, simultáneamente, la correlatividad en sentido dinámi$\mathrm{Co}^{108}$ y la subordinación: "Tercero: esta luz es dicha ser «luz verdadera». En el sentido de que el Padre de la verdad, Dios, es mayor y más grande que la verdad y, siendo el Padre de la Sabiduría, es más excelente y sobrepasa a la Sabiduría; asimismo, sobrepasa a la llamada "luz verdadera»" 109.

\section{B. El Logos es mediador del Padre}

Un primer problema que debemos enfrentar a la hora de hablar del rol mediador del Logos, es el de la simplicidad de Dios y cómo este se relaciona con la multiplicidad de las creaturas. Este es un problema central de la filosofía y, también del judaísmo, donde hallamos algunas mediaciones entre Dios y el mundo, de variada consistencia hipostática, como es el caso de la sabiduría y la palabra, entre otras.

Anteriormente, analizamos este tema a la luz del rol de principio que tiene el Padre respecto al Hijo y a todas las cosas. El texto desde el que debemos comenzar, sin duda, es I, 119, en el que se afirma que:

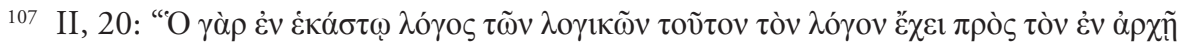

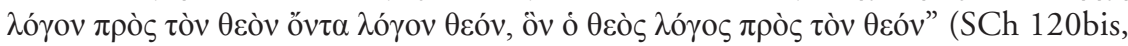
p. 224).

108 Las imágenes utilizadas en II, 52 nos parecen apoyar la coeternidad de la relación pues, como hemos visto, no puede pensarse a un padre sin un hijo, ni a Dios sin su Sabiduría.

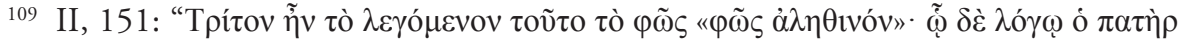

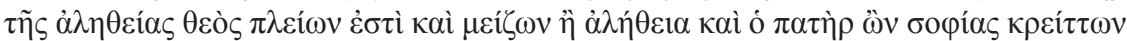

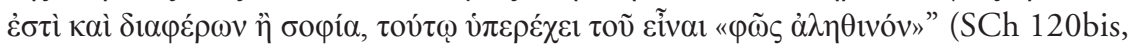
p. 310). Otra cita que apoya esta subordinación es II, 81, donde Orígenes reflexiona el tema a partir de la consideración de las misiones trinitarias. Ahora bien, respecto al tema de la subordinación presente en II, 151 no debe pensarse a nivel de la existencia, como lo muestra Corsini: "per quanto concerne a la conoscenza della verità, non c'è differenza alcuna tra il Padre e in Figlio, dal momento che questi, essendo la verità in sé, la verità sonstanziale, cioè ipostatizzata, "non ignora nulla di ciò che appartiene alla verità" (Cf. I, 187)" (E. CorsinI, "Commento al Vangelo di Giovanni [Libri I-II]: Postille a una Traduzione”, 186-187). 
"Dios es absolutamente uno y simple, pero nuestro Salvador, debido a la multiplicidad ${ }^{110}$, habiendo sido constituido por Dios como propiciación, y primicia de toda la creación, llega a ser muchas cosas, quizá todas, según la necesidad que de él tiene toda creatura que puede ser liberada"111.

Claramente este texto nos pone frente, por una parte, la relación eterna del Hijo y el Padre y, por otra, el rol mediador del Logos. En este contexto, nuestro autor, siguiendo el camino marcado por Clemente ${ }^{112}$, propone una cierta multiplicidad en el seno del Salvador, la cual, parece, es explicada a través de una genial construcción teórica de Orígenes: la llamada doctrina de las epínoiai ${ }^{113}$, la que tiene en el CIo un lugar privilegiado, con abundancia en las imágenes.

En I, 51, el Alejandrino afirma que Jesús es A $\gamma \alpha \theta \dot{\alpha}$, es decir, literalmente, bienes. El hablar en plural de Jesús no debió haber sido algo común, por lo que enseguida dirá:

"Que nadie se asombre si hemos notado que se anuncia a Jesús con el plural bienes, pues si entendemos las realidades significadas por los varios nombres aplicados al Hijo de Dios, comprenderemos cómo Je-

110 En este pasaje el texto simplemente dice " $\delta i \grave{\alpha} \tau \grave{\alpha} \pi \mathrm{o} \lambda \lambda \alpha \alpha^{\prime}$, lo que ciertamente trae un problema hermenéutico. Corsini sumplementa traduciendo "a causa di questi molti [beni]", mientras que Blanc traduce "à cause de la multiplicité [des créatures]". Yo me inclino por la opción de Corsini, pues la multiplicidad de ser bienes de Jesús, es reflejo de las condiciones diversas de las creaturas e, incluso la Sabiduría, es modelo múltiple de lo que será creado (sobre la multiplicidad de la Sabiduría, cf. I, 114-115).

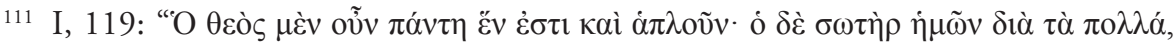

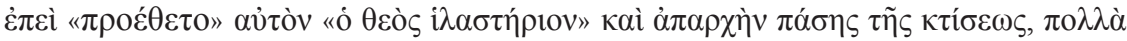

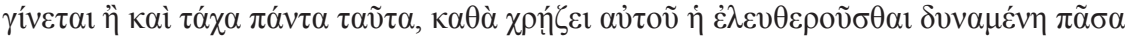

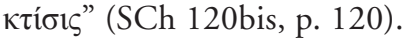

112 Un interesante pasaje, por ejemplo, es el de sus Stromata IV, 25, 156.

113 Una buena visión de conjunto de este tema puede hallarse en H. Crouzel, "Le contenu Spirituel des Dénominations du Christ selon le libre I du Commentaire sur Jean d'Origéne", en H. Crouzel - A. Quacquarelli (eds.), Origeniana secunda (Roma 1980) 131-150; J.A. McGucKIN, The changing forms of Jesus, en L. LIES (ed.), Origeniana quarta (Innsbruck 1987) 215-222 y en J. Wolinski, "Le Recours aux Ė $\pi$ ívoral du Christ dans le Commentaire sur Jean d'Origène”, en G. Dorival (ed.), Origeniana sexta (Louvain 1995) 465-492. Un estudio mayor -por su densidad, más que por su volumen-, es el que provee A. Orbe, La epinoia. Algunos

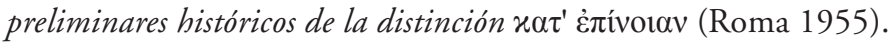


sús puede ser muchos bienes, como es anunciado por aquellos cuyos pies son bellos"114.

Lo que sigue a esta justificación, es una enumeración de diversos nombres aplicados a Jesús por la Escritura, lo mismo que hallamos más extensa y detalladamente en la sección que se abre en I, 125 hasta el final del libro. Los diversos nombres son llamados óvo $\mu \alpha \sigma i \alpha^{115}$, aunque el vocablo técnico que utiliza Orígenes es éxívoı $\alpha$, que podemos traducir por noción o concepto, aunque dada su relevancia técnica, como se ha visto, hemos optado por transcribirla. Este término lo hallamos utilizado con este sentido preciso 15 veces en los libros I y II del comentario ${ }^{116}$, y la cantidad de nombres del Hijo es múltiple ${ }^{117}$.

Ahora bien, esta multiplicidad no debe pensarse como propia de la sustancia del Hijo, residiendo en ella: "ninguno se disguste con que distingamos las epínoiai en el Salvador, ni piense que hacemos lo mismo

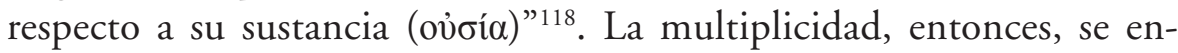
tiende más bien como propia de la forma en que el ser racional percibe o se aproxima al Hijo de Dios: antes de contemplar al Salvador con un nombre (غ̇ंívor $\alpha$ ), el racional contempla su multiformidad salvífica, su noción fundamental ("̌́vvora) ${ }^{119}$.

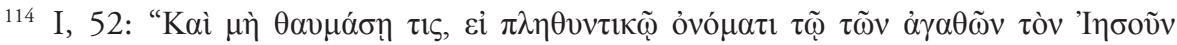

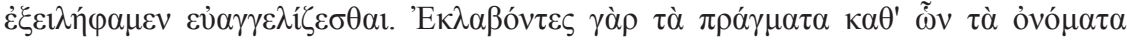

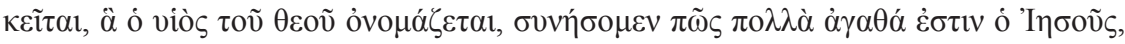

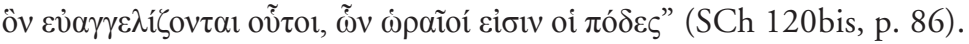

115 Por ejemplo, ver I, 118; 123; 266, entre otros.

116 I, 118; 200; 222; 223; 226; 259; II, 66; 76; 89 (x2); 154; 193; 226; 227; 229.

117 Según Rius-Camps el tratamiento de Orígenes respecto de los nombres responde a la matriz estoica "según la cual los nombres fluyen naturalmente ( lidades mismas, rechazando tanto la doctrina aristotélica, según la cual los nombres fueron impuestos $(\theta \varepsilon \dot{\sigma \varepsilon \varepsilon})$ a las cosas por el hombre, como también la epicúrea, que admitía una cierta correlación entre nombre y cosa como resultado de los primeros balbuceos de los hombres primitivos frente a determinados objetos. Supuesto este postulado, los nombres o denominaciones cobran en su teología un valor conside-

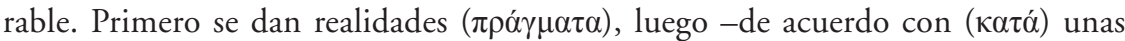
primeras nociones (E่vvolõv) - aparecen los nombres (ỏvó $\mu \alpha \tau \alpha)$ " (El dinamismo trinitario, 119).

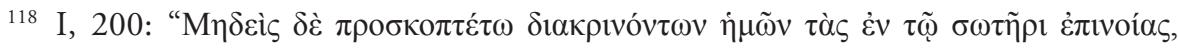

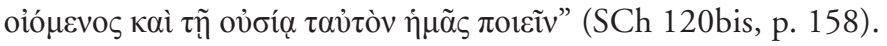

119 Respecto a este tema, cf. J. Rius-CAMPs, El dinamismo trinitario, 120-121. 
Esta multiplicidad, así, tiene que ver con la plenitud inteligible del Salvador, el que tiene la capacidad de satisfacer al pensamiento -múltiple- de las creaturas racionales ${ }^{120}$, siendo un objeto adecuado que se percibe a partir del propio progreso espiritual del ser dotado de razón ${ }^{121}$, lo que Orígenes expresa de modo muy preciso en su CIo:

"Y no es asombroso, como hemos declarado, que siendo el Salvador

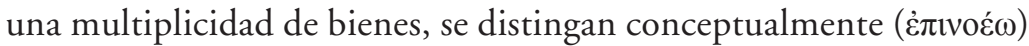
en él [bienes] primeros, segundos y terceros. Juan, en consecuencia, hablando del Logos afirma "lo que llegó a ser en él era vida», de esta forma, pues, la vida llegó a ser en el Logos. Pero, ni es el Logos -el Dios Logos, que está hacia el Padre y por el cual todo fue hecho- diverso a Cristo, ni es la vida diversa del Hijo de Dios, quien dijo «yo soy el camino, la verdad y la vida», de la misma forma como la vida llegó a ser en el Logos y el Logos era en el principio"122.

Hay, en todo caso, epinoiai que el Salvador lleva más propiamente en relación a sí mismo que otras ${ }^{123}$; esto significa, en concreto, que ciertas

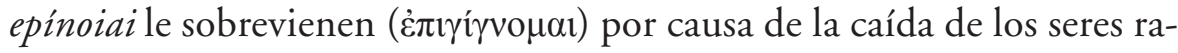

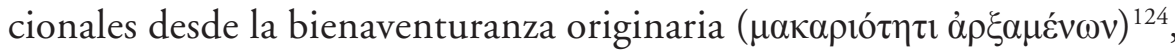
mientras que otras le pertenecen de un modo más propio. En I, 251, distingue, en este sentido, aquello que el Hijo es por nosotros de aquello que es de manera absoluta ( $\dot{\alpha} \pi \lambda \tilde{\omega} \varsigma$ ), lo que según I, 123 puede decirse de Sabiduría, Logos, Vida y Verdad: estas serían las cuatro epinoiai superiores, y que -si bien guardan directa relación con nuestra salvación- son dichas propiamente absolutas del Hijo.

En la extensa enumeración de los títulos, de los cuales todos deben ser considerados cuidadosamente por los creyentes, pues son dichos en sen-

120 De esta forma, entonces, la multiplicidad no está en la sustancia, sino en la comprensión de los racionales.

121 Cf. I, 112.

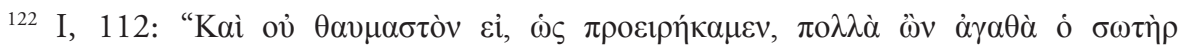

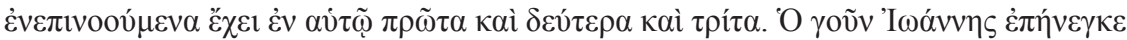

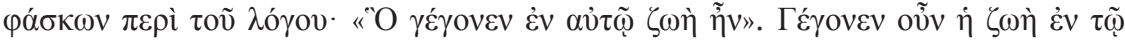

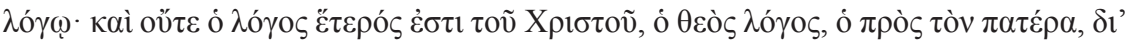

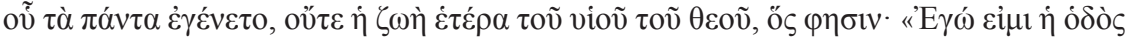

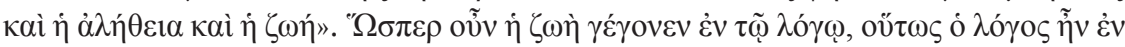

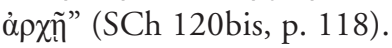

123 Cf. II, 125.

124 Cf. I, 123. 


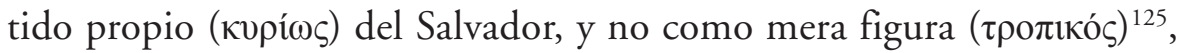
Orígenes tratará de distinguir sistemáticamente las epinoiai que el mismo Hijo se atribuye tanto en el Antiguo como en el Nuevo Testamento ${ }^{126}$ de las que otros le atribuyen. Esta multiplicidad, como es claro en I, 119, corresponde al fin redentor de la mediación del Logos, y se adecua a las necesidades de las creaturas y a sus posibilidades de acceso racional al misterio, lo que está indisolublemente vinculado al progreso espiritual del racional que le recibe, partiendo por percibir los aspectos más simples del Hijo, ascendiendo progresivamente a los más complejos ${ }^{127}$.

Por ejemplo, en el nivel más bajo de las epinoiai, hay hombres que, a causa de su carácter gentil y quieto -pero instintivo-, reciben al Hijo de Dios en cuanto pastor, algo parecido puede decirse en cuanto es rey ${ }^{128}$. En los niveles superiores, hallamos a quienes contemplan las realidades incorporales, invisibles, y estos mediante la acción purificadora del Logos, son "regidos por la naturaleza preeminente del Unigénito" ${ }^{129}$, es decir, por alguna de las epinoiai que hemos llamado superiores.

En este contexto, y siguiendo la propuesta de la primera parte de este artículo, respecto al rol absoluto o general del ser principio del Padre, y que se refleja en esta parte, al afirmar que el Logos recibe todo de él, es necesario decir que las epinoiai, que implican que el Hijo de Dios no sea solo un bien, sino bienes -como presentamos a propósito de I, 51brotan de la bondad del Padre. Este le da al Hijo ser estos bienes: "este es, pues, el que del Padre bueno recibe el ser bienes, para que cada uno, habiendo recibido tal o cual bien que pueda contener, llegue a ser en los

125 Cf. I, 125, donde nuestro autor se asombra de la actitud arbitraria de quienes, sin siquiera entenderlo bien, prefieren un uso exclusivo de $\lambda$ ó ${ }^{\circ} \varsigma$ para referirse a Cristo, sin considerar adecuadamente, por una parte, la multiplicidad de nombres que le aplica la Escritura y, por otra, el sentido preciso en el que debe entenderse que Cristo es $\Lambda$ ó

126 Recordemos que Orígenes, contra gnósticos y marcionitas, sostiene no solo la unidad de ambos testamentos, sino también la venida espiritual, revelación e inspiración total del Logos respecto de los textos de la Biblia.

127 Cf., por ejemplo, I, 201. Respecto a este carácter místico, como trasfondo a todo el tema de las epinoiai, cf. M. FÉdou, La Sagesse et le monde: Essai Sur La Christologie d'Origène (Paris 1995) 239.

${ }_{128}$ Asimilándose en cada caso, respectivamente, a los animales y a los vasallos: cf. I, 198.

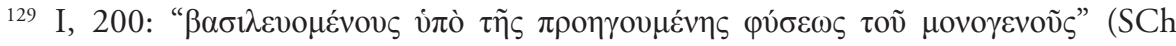
120bis, p. 158). 
bienes"130, es el Padre bueno el que instruye en los bienes ${ }^{131}$, y entre los bienes -tanto aquellos que llega a ser el Hijo, como de aquellos que es desde siempre- el mayor es ser $\operatorname{Logos}^{132}$.

Ahora bien, todas las epinoiai, incluso las superiores, dicen relación con cierta orientación ad extra en Dios pues, incluso la más excelsa -Sabiduría-, está relacionada con los "logoi determinados de antemano por Dios para sus creaturas en su Sabiduría, pues «todo lo hizo en la Sabiduría»" 133 y, en este sentido, si bien las epínoiai superiores parecen designar según los textos a aquello que el Hijo es eternamente frente al Padre, nos parece que el nombre más propio con que se puede designar al Salvador es Hijo o Unigénito -ambos términos están reservados para la filiación particularísima del Logos, pues en el pensamiento de Orígenes solamente el Unigénito es Hijo por naturaleza desde siempre-. De todas formas, pareciera haber una identidad entre la Sabiduría y el Hijo de $\operatorname{Dios}^{134}$.

Respecto a la Sabiduría, junto a lo mencionado en el capítulo anterior, es interesante considerar el pasaje I, 244, en el que nuestro autor afirmará que la Sabiduría existe "más allá de toda creatura" (i் $\kappa \tau i ́ \sigma v)$, presentando así una clave para la comprensión correcta del verbo $\kappa \tau i \zeta \omega$ referido a la Sabiduría ${ }^{135}$, previniendo toda comprensión que pue-

${ }_{130}$ I, 62: "Oṽ̃

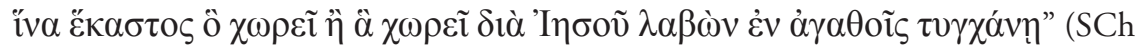
$120 \mathrm{bis}, \mathrm{p}$. 90). Respecto a la bondad del Padre y su carácter exclusivo nos hemos ya referido anteriormente, aunque ahora, a la luz del concepto de imagen, podemos decir que el Hijo es imagen de la bondad, no poseyendo una bondad segunda, sino que la misma del Padre (cf. H. Crouzel, Théologie de l'ímage de Dieu, 96).

131 Cf. I, 65.

132 Cf. I, 57. Ciertamente esta primacía del Logos sobre las demás epinoiai, incluso sobre la Sabiduría es problemática y requiere una consideración sistemática en la obra de Orígenes, lo que escapa a los límites de este artículo. De todas maneras, quien quiera profundizar este tema, puede consultar M. SIMONETTI, "Note sulla teologia trinitaria di Origene”, Vetera Christianorum 8/1 (1971) 287-289.

${ }_{133}$ I, 114, cf. I, 288.

134 Cf. II, 76. A juicio de Simonetti, si el Logos (ciertamente la epínoia más valorada por el Alejandrino) tiene su hipóstasis en la Sabiduría, ello lleva a concluir que la Sabiduría se identifica del todo con el Hijo ("Note sulla teologia trinitaria di Origene", 290).

135 Recordemos que una de las citas, problemática por cierto, que nuestro autor tiene en mente al hablar de la sabiduría es $\operatorname{Pr} 8,22$, donde se afirma que el Padre ha hecho $(\kappa \tau i \zeta(\omega)$ a la Sabiduría como principio de sus caminos. Hay que observar, 
da debilitar la coeternidad. Esta Sabiduría es -como vimos anteriormen-

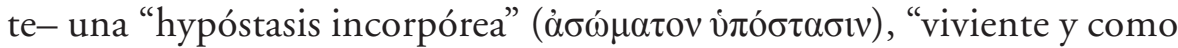

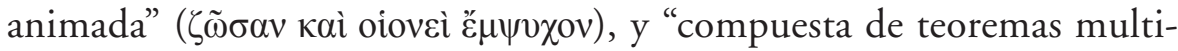
formes que contienen las razones del universo" (

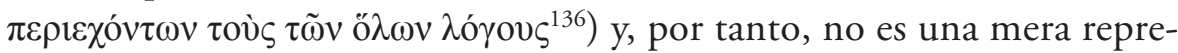

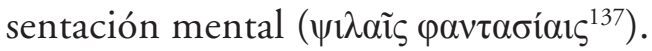

La especial relevancia de la Sabiduría reside en que, permaneciendo en ella, el Logos también es principio, pues no es principio según todas sus epinoiai, sino solamente en cuanto Sabiduría. En este sentido, nuestro autor afirma que: "por esto se puede decir, valientemente, que Sabiduría es la más antigua de entre todas las comprensiones que los nombres del primogénito de toda creatura permite hacer" ${ }^{\prime 38}$.

Esto es posible por la voluntad del Padre, quien ha determinado de antemano en la Sabiduría los typoi de todas las cosas, con el fin de que ella le dé la existencia y forma a la materia y a todos los seres ${ }^{139}$. El ser principio de la creación, que le sobreviene (غ̇лrírvoual) al Hijo por la voluntad del Padre que le ha constituido Sabiduría, le vale al Hijo un título propiamente dicho del Padre: demiurgo ${ }^{140}$, pues la Sabiduría es el principio de los actos de Dios ${ }^{141}$. Ahora bien, hemos afirmado que es

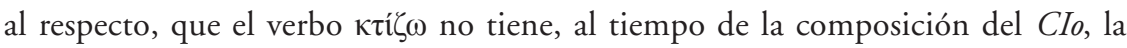
connotación técnica que adquirirá durante el siglo siguiente, a propósito de la controversia arriana. De todas formas, con este "vi $\pi \dot{\varepsilon} \rho \pi \tilde{\alpha} \sigma \alpha v \kappa \tau i ́ \sigma v$ ”, Orígenes busca encausar una correcta interpretación del verbo en cuestión.

136 Cf. I, 114-115. "Ces «théoremes» du Père que le Fils dévoile, ce sont les mystères divins, les vérités contenues en Dieu, et aussi l'ensemble des Idées, logoi et essences, qui forment dans le Fils, à la manière des platoniciens, le monde intelligible, selon lequel le monde sensible a été créé" (H. Crouzel, Théologie de l'image de Dieu, 84).

137 Cf. I, 243.

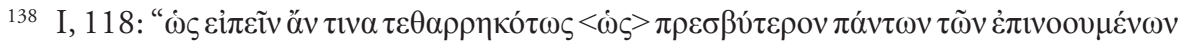

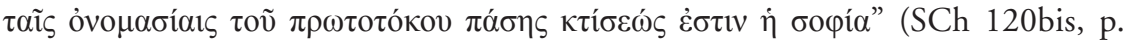
120); Cf. I, 289.

139 Cf. I, 114-115.

${ }^{140}$ Es interesante, respecto a la articulación de los textos bíblicos que hace Orígenes en torno a la creación de todo el universo en la Sabiduría y la relación entre Logos y Sabiduría como creadores, la conclusión al libro primero (I, 289-292). El vocablo

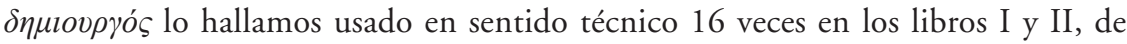
estas veces, 11 aplicado al Padre y solamente cinco al Hijo [Padre: I, 35; 82; 102; 253; II, 102 (x3); 104 (x2); 171; 199; Hijo: I, 110; 111 (x2); 255 (x2)].

141 Cf. I, 108. 
propiamente dicho del Padre, pues Orígenes es muy preciso en mantener el rol eminente del Padre en cuanto principio y demiurgo, asignándole al Hijo un rol de mediador: "Cristo es como demiurgo, pues el Padre le dice «hágase la luz»y «hágase el firmamento»"142.

De esta forma, entonces, hemos visto que el ser del Logos se define desde su recibir todo del Padre, de esta acción -que posee una dinámica eterna- procede el Logos. Este, destinado por el Padre a mediar entre su absoluta unidad y simplicidad y lo múltiple, es el principio de acción ad extra de Dios.

El camino que hemos hecho ha comenzado por mostrar quién es el Padre, algo imposible si no se hace desde el Hijo. Luego hemos visto quién es el Hijo, que recibe todo del Padre y actúa en la creación en cuanto único, y a la vez múltiple, mediador. Es claro que, a partir de las categorías de su tiempo, Orígenes ha elaborado una teología del Padre y del Hijo fuertemente dinámica, basada en la relación entre uno y otro, y en la participación que deriva de esta relación. Ciertamente las soluciones esbozadas por el Alejandrino no dejan de ser problemáticas, sobre todo respecto a la afirmación de la unidad, sin embargo deja pavimentado un camino que, no sin dificultades, se recorrerían más tarde en la crisis monarquiana que marcó al siglo IV. Las proyecciones que brotan también a nivel de la relación entre el Logos y las criaturas racionales son muy interesantes, sobre todo porque toman este modelo relacional que hemos mostrado, y son la base de una doctrina riquísima a nivel místico, marcado por una fuerte afirmación de la libertad, lo que se refleja en el progreso espiritual de las criaturas en el camino de asimilación al Hijo en la contemplación del Padre.

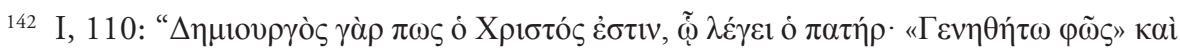

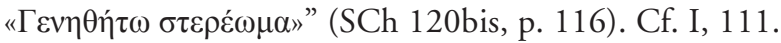

